\title{
Trends in Mongolian Foreign Trade Development by Joining PAA
}

\author{
Tungalag Jargalsaikhan \\ Mongolian National University of Commerce and Business, \\ Trade and Marketing Department, Ass. Prof, Ph.D \\ E-mail: tungalag7881@gmail.com \\ Munkh-Erdene Tuvshintugs* \\ Mongolian National University of Commerce and Business, \\ Trade and Marketing Department, Ph.D Candidate of Jilin University in China \\ E-mail: Munkherdene@nucb.edu.mn \\ Davaanyam Munkh-Erdene \\ MBA Candidate of Mongolian National University of Commerce and Business
}

\begin{abstract}
It has not been a long time since Mongolia adopted market economy but ever since 2004, it has been recording fast development which motivated them well enough to jump into the electronic trade market. Though it has just started, many small and medium size enterprises are already doing their businesses through the internet.This means that they need to arrange new regulations regarding electronic merchant agency in order to support every needed element from e-trade education and consultation for effective support and promotion to e-trade package supply such as business good offices and trade automation. Through the PAA project system which is operated by Korea and other 9 east Asian countries, many enterprises in Mongolia can be introduced to Mongolian websites and Korean business websites. This will benefit both Mongolian economy and Korea-Mongolia cooperation.Therefore, infra system should be firmly constructed in Mongolia in order to for Mongolia to become member of PAA project and gradually enlarge the boundary of its trade market in East Asia.
\end{abstract}

Keywords: PAA, E-Commerce, KOICA, UNDP

DOI: $10.7176 / \mathrm{EJBM} / 13-10-04$

Publication date:May $31^{\text {st }} 2021$

\section{POINTED ISSUE}

Although small and medium enterprises make a significant contribution to the economic development of any country, the trade environment is very limited compared to large enterprises. As a result, nine countries in Southeast Asia are actively implementing a project called PAA (PAN Asian e-Commerce Alliance), a global ecommerce representative to support small and medium enterprises in their respective countries.

However, Mongolia is not able to implement this project due to the lack of e-commerce. Mongolia, which belongs to the Asian region, needs to recognize global e-commerce and join the PAA project without delay in order to successfully continue the economic and foreign trade of other countries in the region. The main purpose of this study was to identify the steps that Mongolia should take and the scope of foreign aid to stimulate Mongolia's foreign trade, expand the use of e-commerce, and join the PAA project, an e-commerce project in Asia.

In order to achieve this goal, the survey was conducted by telephone and the relevant materials were obtained from the Statistical Office of Mongolia http://www.nso.mn, the Statistical Office of the Republic of Korea http://www.nso.go.kr, and the Embassy of Mongolia http: www.mongolembassy.com, and used materials of companies such as: PAA project website http://www.paa.net. Esnet http://www.esnet.go.kr, Korean Center for Foreign Economic Studies http://kiep.go.kr, Ministry of Finance and Economy of Korea http://www.mke.go.kr, email Linked website of trading companies http://www.koica.go.kr, Korean foreign trade and information company http: // www.ktnet.co.kr.

Mongolia established diplomatic relations with South Korea in 1990. Since then, South Korea has provided a wide range of assistance to Mongolia. As of 2021, Korea is the fourth largest investor in Mongolia.

\section{PAA PROJECT MECHANISM AND OPERATION}

The PAA project is a project to connect e-commerce of domestic trading companies with e-commerce companies of Asian countries. The goal of the PAA project is to expand the integrated e-commerce service into a global ecommerce network based on the Internet, with a focus on digitalizing trade and commerce regulations, and to create an e-commerce infrastructure system that digitizes all international trade. 


\section{- Pan-Asian e-Commerce Alliance (PAA)}

$\Rightarrow$ To-date: 11 member economies; KTNET (Korea), CIECC (China), Tradelink (Hong Kong), TEDMEV (Macau), Trade-Van (Chinese Taipei), NACCS (Japan), CrimsonLogic (Singapore), DagangNet (Malaysia), CAT (Thailand), PTEDI (Indonesia), InterCommerce (Philippines)

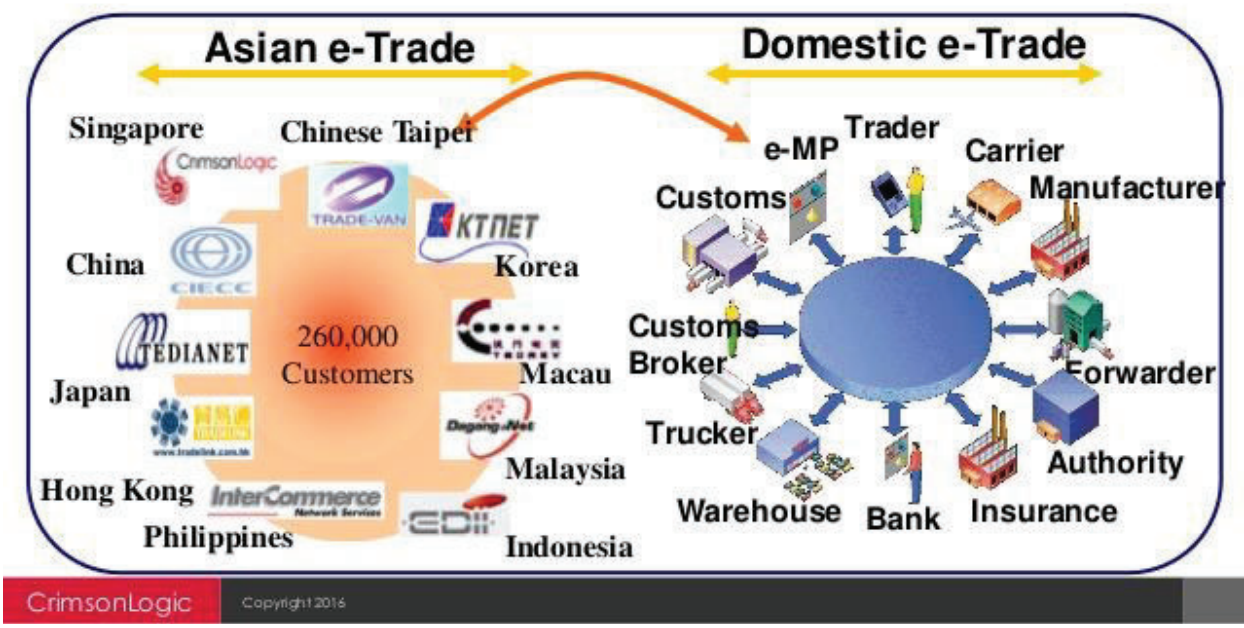

Figure 1. PAA

The PAA project uses e-commerce to provide services such as international trade, transportation, and electronic payments to APEC's 21 countries, ASEM 39 countries, and AFACT 17 countries.

For example: pre-customs declaration, e-freight listing between 2 international companies, or between business and government (B2G) services, trade order (P / O), trade order verification, countries with B2B service, $\mathrm{P} / \mathrm{L}$, and e-CIOs, as well as $\mathrm{B} 2 \mathrm{G}$ services is an activity that distributes international services to countries all over the world. In order to implement this service, security, document standardization, and networking are essential.

The PAA project provides global e-commerce services.

$1^{\text {st }}$, International electronic document exchange and services

$2^{\text {nd }}$, Export and Import Information Exchange Services,

$3^{\text {rd }}$, Determine the location of the goods being transported

$4^{\text {th }}$, the PAA Project Portal Service manages the Home Page and provides information as a business directory for the PAA Trade Area.

The economic benefits of the PAA project

Small and medium-sized enterprises should be able to recognize and join the PAA project, as it will benefit businesses and cover a wide range of benefits. Based on the following material, the economic viability of the PAA project can be predicted. The table below №1 is a study of 9 model companies implementing the South Korea's PAA project. These companies have shown that the project can save a certain amount of money in many ways, such as increasing wages, saving, saving sales and delivery time, reducing sales stages, and reducing warehouse costs.

According to the study, the PAA project is expected to save a minimum of $6,720,000$ won and a maximum of $189,800,000$ won. The implementation of the PAA project will increase trade, supply and reduce costs. 
Table 1.Results of the PAA project survey

\begin{tabular}{|c|c|c|c|c|c|c|c|c|c|c|}
\hline & 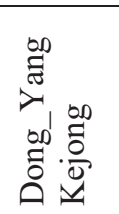 & $\begin{array}{l}\text { ¿ } \\
\text { E } \\
\vdots\end{array}$ & 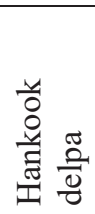 & 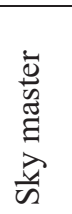 & 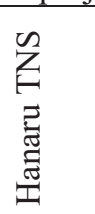 & $\begin{array}{l}\text { ]ี } \\
\text { Dి } \\
0 \\
0\end{array}$ & 哥 & $\begin{array}{l}\stackrel{\infty}{\Xi} \cdot \frac{\pi}{\Xi} \\
\stackrel{0}{\Xi} \\
\stackrel{\Xi}{\Xi}\end{array}$ & 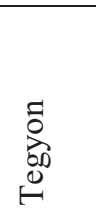 & $\stackrel{\overparen{\pi}}{\stackrel{0}{0}}$ \\
\hline Save wages & 140 & 9 & 40 & 24 & 30 & 160 & 80 & 170 & 140 & 793 \\
\hline $\begin{array}{l}\text { Shorten the } \\
\text { delivery time }\end{array}$ & 0 & 0 & 3.6 & 3.6 & 6 & 0 & 3.6 & 0 & 0 & 16.8 \\
\hline $\begin{array}{l}\text { Reduce the level } \\
\text { of foreign trade }\end{array}$ & 23.4 & 48 & 24 & 3.6 & 4.8 & 42 & 24 & 17.4 & 23.4 & 210.6 \\
\hline $\begin{array}{l}\text { Reduce storage } \\
\text { costs }\end{array}$ & 24.53 & 21.6 & 6 & 36 & 60 & 9 & 6 & 2.4 & 4.8 & 170.33 \\
\hline $\begin{array}{l}\text { The total size of } \\
\text { each organization }\end{array}$ & 187.93 & 78.6 & 73.6 & 67.2 & 100.8 & 211 & 113.6 & 189.8 & 168.2 & $1,190.73$ \\
\hline
\end{tabular}

Sourse: KTNET Project Survey Results (January 2005)

Research on Mongolia's foreign trade sector to be involved in the PAA project.

In order to develop e-commerce in Mongolia through the PAA project, it is necessary to study Mongolia's foreign and domestic trade. This is because the PAA project will take into account the current level of Mongolia's foreign trade environment.

\section{CURRENT MACROECONOMIC SITUATION OF MONGOLIA AND FUTURE PROSPECTS}

\subsection{Economic growth}

The mining, agriculture, processing and trade sectors have had a high share of net taxes on their products for the last 20 years, accounting for an average of 65 percent of GDP a year since 2010. For example, mining accounts for 22 percent, agriculture for 11 percent, processing for 6 percent, trade for 14 percent, and net taxes on products for 11 percent. Therefore, changes in these sectors have a significant impact on GDP growth and decline.

Mongolia's economic growth (real GDP growth) has been growing rapidly since 2000, largely due to mining and manufacturing, and reached its highest level in 2011 at 17.3 percent. However, economic growth has slowed since 2012, reaching 1.2 percent in 2016. After that, the economy recovered and real GDP growth reached 5.1 percent in 2017.

Table 2. Real GDP growth

\begin{tabular}{|l|l|l|l|l|l|l|l|l|l|}
\hline & $\begin{array}{l}\text { GDP / net } \\
\text { growth, } \\
\text { decline, } /\end{array}$ & GDP / price/ & $\begin{array}{l}\text { GDP per } \\
\text { capita / } \\
\text { thousand } \\
\text { MNT/ }\end{array}$ & $\begin{array}{l}\text { Human } \\
\text { developme } \\
\text { nt Index }\end{array}$ & Export & Import & Workforce & $\begin{array}{l}\text { Unemployment } \\
\text { rate /\%/ }\end{array}$ & $\begin{array}{l}\text { Inflation } \\
\text { rate /\%/ }\end{array}$ \\
\hline 2010 & 6.4 & $9,756,588.3$ & 3697.6 & 0.756 & $2,908,502.2$ & $3,200,053.3$ & $1,147,146$ & 9.9 & \\
\hline 2011 & 17.3 & $13,173,763.4$ & 4917.1 & 0.709 & $4,817,496.4$ & $6,598,358.1$ & $1,124,711$ & 7.7 & 10.1 \\
\hline 2012 & 12.3 & $16,688,419.6$ & 6107.2 & 0.718 & $4,384,669.2$ & $6,738,380.7$ & $1,151,146$ & 8.2 & 9.2 \\
\hline 2013 & 11.6 & $19,174,242.6$ & 6867.9 & 0.726 & $4,269,55.8$ & $6,357,821.8$ & $1,198,333$ & 7.9 & 14.3 \\
\hline 2014 & 7.9 & $22,227,054.3$ & 7716.3 & 0.735 & $5,774,330.9$ & $5,236,667.8$ & $1,206,554$ & 7.9 & 10.5 \\
\hline 2015 & 2.4 & $23,150,385.6$ & 7810.3 & 0.736 & $4,669,280.5$ & $3,797,519.1$ & $1,243,895$ & 7.5 & 12.8 \\
\hline 2016 & 1.2 & $23,942,866.4$ & 7910 & 0.733 & $4,916,335.4$ & $3,358,140.3$ & $1,275,650$ & 10 & 6.6 \\
\hline 2017 & 5.3 & $27,876,297.22$ & 8999.1 & 0.732 & $6,200,593$ & $4,337,322.4$ & $1,357,425$ & 8.8 & 0.7 \\
\hline 2018 & 7.2 & $32,411,224.1$ & 10259.8 & 0.739 & $7,011,765$ & $5,874,803.8$ & $1,358,637$ & 7.8 & 4.3 \\
\hline 2019 & 5.159 & $37,392,629.06$ & 11680.618 & 0.744 & $7,619,753.9$ & $6,127,438.8$ & $1,273,896$ & 10 \\
\hline 2020 & -5.336 & $37,329,545.7$ & 11459.5 & & $7,576,319.5$ & $5,293,939.4$ & & 6.8 \\
\hline
\end{tabular}

Source: www. mongolbank.com

Table 3. Mongolia's Macroeconomic Growth and Future Forecasts

\begin{tabular}{|l|l|l|l|l|l|}
\hline & 2021 & 2022 & 2023 & 2024 & 2025 \\
\hline $\begin{array}{l}\text { GDP growth,\% } \\
\text { / Forecast of the Ministry of Finance / }\end{array}$ & 6.0 & 5.5 & 5.0 & 5.0 & 5.0 \\
\hline $\begin{array}{l}\text { GDP growth,\% / NDA Research Team } \\
\text { Estimates, Medium Scenario / }\end{array}$ & 5.0 & 5.6 & 6.0 & 6.3 & 7.0 \\
\hline $\begin{array}{l}\text { In GDP price, billion MNT / Estimation of } \\
\text { NDA Research Team, medium version / }\end{array}$ & 42860 & 46851 & 51931.3 & 56472 & 61647.1 \\
\hline $\begin{array}{l}\text { Imports / Estimates of PDA Research } \\
\text { Team / }\end{array}$ & 25596.6 & 27174.1 & 29081.5 & 30494.9 & 32056.5 \\
\hline $\begin{array}{l}\text { Inflation rate / Estimation of NDA } \\
\text { Research Team / }\end{array}$ & 6.3 & 5.9 & 7.4 & 5.2 & 8.2 \\
\hline
\end{tabular}

Source: www.mongolbank.com 
Mongolia's economy has grown significantly since 1995, largely dependent on mining and manufacturing, and real annual GDP growth reached 17.3 percent in 2011. However, real GDP growth has been declining since 2011, reaching 1.2 percent in 2016 and 5.1 percent in 2017, when the economy recovered.

The unemployment rate reached 10 percent in 2019, and the number of unemployed decreased by 22.1 thousand from 2018.

\subsection{Current state and prospects of e-commerce infrastructure in Mongolia}

The first e-service system in Mongolia has launched 25 years ago, in 1996. As of 2019, the number of Internet users in Mongolia is 5.5 million, which is 2.9 times more than in 2014. This has led to a sharp increase in the number of Internet users with the introduction of the 3G network in 2014 and the LTE network in 2016, and the trend of people using mobile phones and the Internet to purchase and use services is growing. Aimed at making ecommerce regulation easier in Mongolia, meets international legal requirements, the law on Electronic Signatures was adopted on 15 December 2011 and provides for the legal regulation of electronic signatures to create a legal framework. The law on electronic signatures was effective January 1, 2013.

This law regulates the conclusion, amendment, cancellation, and digital signature of contracts and agreements related to e-commerce under the Civil Code. According to the "General Terms and Conditions and Regulations for Digital Content Services" approved by the Communications Regulatory Commission on September 25, 2014, the website registers for a period of two years but is not classified by type of activity. There are e-commerce sites in Mongolia such as www.dalai.mn, www.eshopping.mn, www.shoppy.mn, www.ard.mn and also there are merchants through their blogs and social media accounts. However, there are currently no specific regulations governing the trade and communication of these sites. There is also a lack of unified registration and statistics on e-commerce. According to Article 8 of the Law on Telecommunications, the Communications Regulatory Commission (CRC) approved a temporary regulation on e-commerce in November 2011, 10 years ago.

"E-Mongolia Program":

Mongolia implemented the e-Mongolia National Program in 2005-2012, the National Program to Establish a Unified Registration System in 2008- 2012 and the National e-Government Program in 2012-2016. Mongolia's long-term development policy, Vision 2050, and the Government's Action Plan for 2020-2024 include the phased digitalization of public services. In this context, the Communication and Information Technology Agency (ITCA) officially introduced the "E-Mongolia" e-service system to the public on October 1, 2020. As of today, 181 services of 23 government organizations have access to the system. According to a survey conducted by the Mongolian Chamber of Commerce and Industry, in 2019, there were 3,800,000 duplicate mobile phone users in Mongolia, of which 2,439,000 were smartphone users. There are 2,910,000 Internet users. Interestingly, as of 2019, the number of Facebook users in Mongolia is 2.2 million, of which 2.1 million are mobile users. This is a very high number compared to Mongolia's 3.3 million population. Interestingly, the average time to use Facebook internationally is 53 minutes, compared to 77 minutes in Mongolia. According to a study, 1.7 million people currently use the "Ebarimt" electronic tax system, which was introduced in 2016, and 500,000 people log in daily. In other words, about $85 \%$ of the 2.1 million adults in our country use the electronic tax system.

As of March 24, 2020, 330, 17188 per week, 143996 per month, and a total of 774892 users applied for e-services.

Table 4. Internet users informaion

\begin{tabular}{|l|l|l|l|l|l|l|l|l|}
\hline & $\begin{array}{l}\text { Number } \\
\text { of cable } \\
\text { TV }\end{array}$ & $\begin{array}{l}\text { Number of } \\
\text { cable TV } \\
\text { users }\end{array}$ & $\begin{array}{l}\text { Number of } \\
\text { mobile } \\
\text { phone } \\
\text { users }\end{array}$ & $\begin{array}{l}\text { Number of } \\
\text { Internet } \\
\text { users }\end{array}$ & $\begin{array}{l}\text { Number of } \\
\text { enterprises } \\
\text { to do } \\
\text { service on } \\
\text { the } \\
\text { internet }\end{array}$ & $\begin{array}{l}\text { The } \\
\text { number } \\
\text { of } \\
\text { Internet } \\
\text { cafes }\end{array}$ & $\begin{array}{l}\text { Payment } \\
\text { card } \\
\text { number }\end{array}$ & $\begin{array}{l}\text { International } \\
\text { card } \\
\text { transactions } \\
\text { / million } \\
\text { USD / }\end{array}$ \\
\hline 2010 & 11 & 178,000 & $2,102,864$ & 162,450 & 77 & 200 & $1,538,336$ & \\
\hline 2011 & 18 & 293,124 & $2,122,694$ & 401,825 & 85 & 180 & $2,169,838$ & \\
\hline 2012 & 16 & 452,100 & $2,060,793$ & 578,043 & 67 & 158 & $2,855,378$ & \\
\hline 2013 & 19 & 516,697 & $1,745,465$ & 633,388 & 55 & 205 & $3,456,440$ & \\
\hline 2014 & 18 & 682,101 & $1,772,222$ & $1,549,766$ & 59 & 318 & $3,574,646$ & \\
\hline 2015 & 18 & 712,616 & $1,967,289$ & $2,029,050$ & 66 & 271 & $4,058,900$ & 123 \\
\hline 2016 & 19 & 869,622 & $1,964,388$ & $2,210,000$ & 60 & 378 & $3,953,989$ & 112 \\
\hline 2017 & 19 & 898,185 & $2,202,679$ & $1,510,800$ & 78 & 452 & $3,844,630$ & 242 \\
\hline 2018 & 19 & 925,199 & $2,289,526$ & & 72 & 497 & & 312 \\
\hline 2019 & 19 & 917,532 & & & 64 & 338 & & 347 \\
\hline 2020 & & & & & & & & \\
\hline
\end{tabular}

Source: www.1212.mn

In a single word, the current information situation in Mongolia can be described as ICT education (distance 
education). The DLC project will connect Information Communication Technology (ICT) management software between Ulaanbaatar and 21 cities. As a result, there are still two centers and two levels of operation in 14 aimags and Ulaanbaatar.

There are 6 universities in Mongolia to train IT professionals. However, there is currently a shortage of IT professionals in Mongolia. The initial phase of the Mongolian government's plan includes a study of the current situation, a bench marketing study, and a detailed technology study.

1. Implementation plan

2. Digitization of Mongolia

3. ICT development in Mongolia until 2010

4. Medium-term ICT sector development strategy in Mongolia

5. ICT Mid-Term Development Strategy Implementation Plan

We conducted a telephone interview with experts from relevant organizations to find out whether Mongolian domestic trading companies fully understand e-trade. The telephone interviews of the relevant experts from the 10 Mongolian trading companies were almost identical. It is true that cashmere garments, gold, molybdenum, copper, meat and meat products are exported and other household goods are imported. There are many difficulties in exporting. As a landlocked country, transportation is very difficult. Shipping takes approximately 21-30 days, and they aimed to decrease the shipment time to approximately 7 days.

The company said it was using an Internet site, but was in fact exporting without an IT or a single e-commerce expert. All staff said they had little knowledge of e-commerce. When asked about the PAA project, most respondents said they had never heard of it before, but the introduction of the project was well received. In fact, they want to increase their exports, but find it difficult to find foreign trade partners. When asked what areas the Mongolian government, the South Korea's government and international organizations need to focus on in order to develop exports and imports, he said that it would be good if the Mongolian government considered the foreign trade sector and resolved tax issues in a positive way.

First of all, many believe that if the Mongolian government pays attention to its people and discusses the issue, it will increase the support of international organizations and foreign governments. The Mongolian government needs to pay attention to its foreign trade companies and find ways to enter the world market. One way to do this is to join a PAA project. Mongolian foreign trade companies are very interested in the PAA project and are unable to implement it in practice due to lack of understanding of the sector. The main topic of the survey with Mongolian trading companies was the PAA project, which highlighted the benefits of Mongolia's participation in the Mongolian economy and the trading companies operating in Mongolia. Therefore, the Mongolian economy needs to accept this proposal and join the PAA project.

\section{SWOT ANALYSIS OF THE MONGOLIAN ECONOMY}

Examining the internal strengths and weaknesses of the Mongolian government and trading companies, as well as the opportunities and ways out of external factors, are as follows.

Table 5: SWOT study of the Mongolian economy

\begin{tabular}{|c|c|}
\hline Strengths & Opportunities \\
\hline $\begin{array}{l}\text { - More than } 80 \text { natural resources that can be developed } \\
\text { - Beautiful, pristine nature, immeasurable steppes, rich in } \\
\text { livestock products } \\
\text { - Willing to develop a market economy and foreign trade } \\
\text { - Russia, China and Central Asia are neighboring } \\
\text { countries with hidden economies } \\
\text { - Established foreign relations with North and South } \\
\text { Korea at the same time } \\
\text { - Strong economic relations with South Korea } \\
\text { - We need the support of the government and the people } \\
\text { for change and reform. } \\
\text { The government has the potential to introduce significant } \\
\text { international commodity projects, such as the Asian } \\
\text { Highway and the Asian Railway, which will significantly } \\
\text { exploit mineral resources and infrastructure. } \\
\text { - Ability to increase information technology and } \\
\text { intellectual investment. }\end{array}$ & $\begin{array}{l}\text { - Information about reform and public confidence } \\
\text { - Active involvement of the government in the } \\
\text { development of natural resources and } \\
\text { infrastructure } \\
\text { - A straight highway connecting the two continents } \\
\text { - Introduce international products and their } \\
\text { renewal projects } \\
\text { - Increase investment in the information } \\
\text { technology sector } \\
\text { - Increase the opportunities for foreign and civil } \\
\text { enterprises to operate based on significant support } \\
\text { from developed countries and the international } \\
\text { community (investment support) } \\
\text { - Mongolia-South Korea cooperation will be } \\
\text { continued } \\
\text { - Focus on environment and tourism. }\end{array}$ \\
\hline
\end{tabular}




\begin{tabular}{|l|l|}
\hline \multicolumn{1}{|c|}{ Weaknesses } & \multicolumn{1}{|c|}{ Threats } \\
\hline $\begin{array}{l}\text { - Landlocked } \\
\text { - Lack of infrastructure, railways, road transport, } \\
\text { information technology }\end{array}$ & $\begin{array}{l}\text { - Competition for mineral resources in developed } \\
\text { countries such as Russia, China, America, Canada } \\
\text { and Japan }\end{array}$ \\
- In the age of globalization, there is a lack of information & $\begin{array}{l}\text { Economic downturn due to excessive } \\
\text { technology and foreign trade specialists } \\
\text { - The domestic market is small } \\
\text { - Lack of market economy experience } \\
\text { - Outdated equipment and insufficient production } \\
\text { - Lack of funds }\end{array}$ \\
\hline
\end{tabular}

Source: Research work

\subsection{Coordination and design of e-commerce and PAA project of Mongolian trade organization}

So far, Mongolia's participation in the PAA project is very poor. However, with the support of South Korea, a powerful IT country and a developed e-commerce country, Mongolia can participate in the PAA project. Now let's plan a system to coordinate the foreign trade of Mongolian trade organizations and the PAA project.

\subsubsection{The current state of Mongolia's foreign trade and issues of concern}

It is less than 20 years since Mongolia emerged from the old socialist system, and as a country that has only recently begun to trade with the rest of the world, Mongolia's level of trade education is very low. Until now, the trading countries have generally been very limited to China and Russia, and small and medium-sized enterprises have been limited to wool and cashmere products and have not gone beyond trade.

The fixed assets of Mongolian trade organizations are exactly 5 hundred million MNT (USD 500 thousand) and the annual sales amount is no more than 3-7 hundred million (USD 300-700 thousand). However, if these organizations can use the PAA project, Mongolian small and medium enterprises will be able to do better business, and through this, the development of small and medium enterprises will be directly linked to the Mongolian economy.

Due to the current shortage of trade professionals in Mongolia's foreign trade organizations, the support of South Korea's trade education experts with experience in foreign trade is urgently needed.

4.1.2 Trade Organization Reform and Support in Mongolia: The Use of South Korea's Small and Medium Enterprise Export Promotion System

There is a way for Mongolian companies to use e-Esnet in South Korea to expand their sales activities.

The e-Esnet service helps small and medium enterprises in South Korea overcome difficulties in exporting. Small and Medium Enterprises (htpp://www.smba.go.kr) can use the "Small and Medium Enterprise Export Assistant (e-Esnet)" to get help at a lower cost.

In order to solve the export problem, small and medium enterprises provide various forms, consultations and services, such as registering online at (http://www.esnet.go.kr) and selecting an export specialist, as well as analyzing materials and consulting.

Mongolian small and medium-sized enterprises can apply for e-Esnet services directly, or in cooperation with the governments of the two countries, which will be of great help to Mongolian trade organizations.

For example, the system supports local South Korea's companies, but if also supports small and medium-sized enterprises in Mongolia, where economic cooperation is strengthening, the two countries' political, economic, and foreign relations will deepen. Because the current situation in Mongolia is support needed of other countries to start e-commerce with the cooperation.

In case, South Korea provides grants to Mongolia every year, and some of that aid could be invested in this sector. 4.1.3 Support for Mongolian e-commerce organizations: Use of South Korea's e-commerce companies The Mongolian foreign trade organization uses e-commerce, and there is a way to use the "e-commerce company" system used in South Korea. In addition to the company's trade-related support, the Mongolian trading company can receive a variety of support to use e-commerce.

An "e-commerce company" is a system that supports small and medium-sized enterprises by establishing a professional organization to support e-commerce marketing through support all export activities up to the contract, as well as finding customers for small and medium enterprises that lack foreign marketing skills. The Ministry of Knowledge and Economy summarizes and the South Korean Trade Association manages the activities.

The "e-commerce company" actively uses the horizontal market position, to supports the small and medium enterprises who has a lack of trade marketing skills for communicate with foreign buyers and commercial intermediaries, e-catalogs, even subscription programs also, generally provide executive services on all trade operation after contract.

An e-commerce company has a key role to play in selecting a specific organization for each company and providing all the services needed by the organization to achieve e-commerce results in a short period of time. 
4.1.4 Operation and direction of the PAA project, in which a Mongolian trading company uses e-commerce skills

As mentioned above, we would like to take the following steps to support Mongolian domestic companies in their foreign trade activities and to participate in the PAA project.

1. Support is needed to establish a Mongolian e-commerce company.

The PAA project is the sole responsibility of e-commerce in Asia, and if Mongolia wants to join the PAA project, it needs to set up an e-commerce company like KTNET (South Korea's foreign trade and information and communication company).

Looking at the current situation in Mongolia, the place where a trade information and communication company can be established in Mongolia is the Mongolian IT Bank, which is established with South Korea's support. The Mongolian IT Bank will create jobs related to e-commerce, which can be called MTNET (Mongolian Foreign Trade, Information and Communication Company). The establishment of a hardware company will rely on South Korea's support to increase its participation in the PAA project, an Asian e-commerce project.

In the future, if Mongolia's foreign trade is stimulated, the Mongolian government will be able to establish a Mongolian foreign trade and information and communication company. At present, Mongol IT Bank needs more trade professionals than advanced software staff. Under KOICA's support for South Korea-Mongolia economic cooperation, sending South Korea's IT specialists to Mongolia and training skilled trade and IT personnel will help to establish a start-up company.

2. The establishment of laws and systems is urgently needed.

If Mongolia joins the PAA project, it will first need to have a domestic law and system. First of all, we need to introduce a new e-commerce law or include the e-commerce law in the foreign trade law. This is because the PAA project needs legal and systemic support.

The e-commerce Promotion Committee, a South Korea's e-commerce system, is a must-have in Mongolia as well. Today, South Korea has become a strong IT country as a result of its efforts to develop e-commerce, such as launching an "e-Commerce Promotion Committee" and setting up a working group to support its work.

Mongolia also needs to work hard for the development of e-commerce. The key question is how effectively Mongolia (Mongolian foreign trade information and communication company: MT-NET) is acquiring information and services related to South Korea (KTNET).

3. There is an urgent need for technical standardization in e-commerce.

E-commerce standards in Mongolia should strive to uphold global e-commerce technical standards, such as the United Nations Chamber of Commerce and the e-Business Center (UN / CEFACT), and develop international cooperation on e-commerce and technical standards. This is because Mongolia's e-commerce standards will be mutually approved in accordance with global e-commerce standards such as UN / CEFACT.

In addition, the Mongolian government should strive to bring its domestic e-commerce system in line with global standards, to harmonize inconsistent standards and to coordinate international cooperation successfully.

Foreign trade standards as UN / CEFACT are already established in the world. If Mongolia needs to establish a new standard now, it would be beneficial to follow UN / CEFACT, which is already an intensive theory in the world.

Currently, in order to get support for e-commerce and software related to RAA projects from South Korea, first needed the help of the places that South Korea International Cooperation Agency (KOICA) (http://www.koica.go.kr), Social Development Assistance (ODA), and the United Nations Development Program (UNDP) http://www.undp.com).

The following is a list of specific assistance directions through KOICA and UNDP.

$1^{\text {st }}$, Mongolian e-commerce and PAA project assistance through South Korea's KOICA.

South Korea-Mongolia e-commerce and PAA project support funds the South Korea International Cooperation Agency (KOICA) 's Official Development Assistance (ODA) is expected to direct the funds.

In 2006, KOICA provided grant assistance to Mongolia that 15 interns, 3 specialists, 23 members of the overseas service team, 1 person in the treatment team, 3 people from development research, 2 people with the material support, 3 staff for project support, and NGOs 1 specialist.

Mongolia is in dire need of KOICA's ODA funding foreign trade and IT. To do this, we need to ask for new aid in this sector, or now redistribute some of the aid money and increase investment in this sector.

As South Korea has a relatively high position in the world in the field of IT and foreign trade, it needs to strengthen support and investment at the level of Mongolian politics, economy and foreign relations.

Looking at today's global trends, Mongolia has become one of the priority sectors for e-commerce development. Joining the PAA project to expand foreign trade with other countries through e-commerce is the fastest way to Mongolia's economic development. To this end, Mongolia needs to use South Korea's ODA assistance in ecommerce education and PAA projects.

KOICA is primarily involved in the development of ICT policies in countries where information and communication technology (ICT) is still in its infancy. There is a government-level ICT, and a country with 
insufficient infrastructure policy and an information and communication infrastructure is helping to build an information and development system.

The performance targets of the KOICA Assisted ICT Sector are as follows.

Objective 1: The ICT sector will help in the development of human resources through the development of ICT education, training development and technology.

Objective 2: e-Government development can enhance the efficiency of developing countries' government work through the informatization of developing government governments, as it supports the development of egovernment, such as computerization in developing countries.

Objective 3: Improving ICT techniques will ultimately improve the work environment through the use of useful, job-oriented information that supports online-based ICT techniques, and the development of economic, social, and cultural information and quality of life in developing countries.

$2^{\text {nd }}$, the direction of Mongolia's economic support through UNDP

The UNDP (United National Development Program) exists to provide technical assistance to accelerate the economic and social development of developing countries. As Mongolia is a UN Member State, so have opportunity to seek assistance from (UNDP). UN has been supporting the Mongolian market economy and democracy from 2007 to 2011 through a standardized program.

The goals of the program are Mongolia's economy, democracy, environmental development and global cooperation. The four UN goals are the most urgent for Mongolia. UNDP is now providing comprehensive support to Mongolia, but it is also needed in the IT and foreign trade sectors. This will require new assistance in this area, or a redistribution of part of the aid funds to develop investment in this sector. Mongolia needs technical assistance to establish a Mongolian foreign trade information company from UNDP.

\section{CONCLUSION}

From South Korea's point of view, Mongolia is a country that has a lot of natural resources economically and is politically similar to North Korea, so it will have a great impact on South Korea's unification. Introducing Mongolian small and medium enterprises to Mongolian sites or South Korea's trade sites through the PAA project, which operates not only in South Korea but also in 9 East Asian countries, will greatly contribute to the Mongolian economy and Mongolian small and medium enterprises.

There is a need to establish a Mongolian e-commerce system to join the PAA project, and continue the program to expand Mongolia's foreign trade in East Asia. Mongolia's economy has unlimited opportunities to develop a wide range of sectors, including vast natural resources and beautiful nature.

However, with the recent transformation into the free market economy, there is a lack of experience in foreign trade and IT. Development in this area begins with a national system plan and a bold investment in the education of skilled employee and contacts with developed countries. To this end, a policy to train Mongolian e-commerce professionals and a policy to accelerate industrial e-commerce is a priority for the Mongolian government. KOICA's ODA Financial Aid is also needed in the field of external relations and IT. To do this, we need to demand new assistance in this area, or redistribute some of the funds to accelerate investment in this sector. South Korea has a strong position in IT and foreign trade. And because of its geographical proximity to Mongolia, highly relies on South Korea's assistance and investment. In order to close the gap in information in developing countries and improve the external output of IT activities, enhance credit and grant cooperation. And development of information communication and e-government services such as IT services, policies of information communication, and human resource development, we need a support.

\section{References}

Foreign Economic Policy Research Center (KIEP) (2006), Country File Mongolia

Yun Guan Un, Kim Chol Hu (2004) Objectives and Perspectives of the Global E-Commerce Network, Korea International Trade Research Conference "International Trade Research" Volume 10, Chapter 1

E Jung San (2005) Research on the reality and development trends of e-commerce companies. Sung Kyun Kwan University, Management Academy

E Bung Su (2006) Research on strengthening the global e-commerce network

State Customs Tax Academy, Customs Tax Department 5 volumes, 1 chapter

The Ministry of Industry and Mineral Resources has a new integrated policy for the development of e-foreign trade, $(2001,2005)$

Global e-commerce materials

Jong Jie Wan, Yu Ming U "Trends in expanding the Mongolian economy and South Korea-Mongolia economic cooperation"

Center for Foreign Economic Policy and Research (KIEP)

Jong Jie Wan (2006), Current state of the Mongolian economy and South Korea-Mongolia economic cooperation, 118 New Economic Ideas in Northeast Asia 
Mongolian Trade Agency (2020), "Mongolian Trade and Economy"

Mongolian statical agency( 2020)

"State Statical Office of Mongolia"

Esnet (http://www.esnet.go.kr)

Ministry of Knowledge economy (http://www.mke.go.kr)

E-foreign trade company (http://www.ec21.com http://www.ecplaza.net)

Korean International Cooperation Fund KOICA (http://www.koica.go.kr)

Korean foreign trade information and communication company (http://www.ktnet.co.kr)

Mongolian Embassy (http://www.mongolembassy.com)

Mongolian bank (http://www.mongolianbank.mn)

Mongolian IT bank (http://www.itpark.mn)

National Statistical Office (http://www.nso.mn)

PAA (http://www.paa.net) 